\title{
The Role of Zooplankton in
} Establishing Carbon Export Regimes in the Southern Ocean - A Comparison of Two Representative Case Studies in the Subantarctic Region

\section{OPEN ACCESS}

Edited by:

Carol Robinson,

University of East Anglia,

United Kingdom

Reviewed by:

Santiago Hernández-León,

University of Las Palmas de Gran

Canaria, Spain

Geraint A. Tarling,

British Antarctic Survey,

United Kingdom

Bernard Quéguiner,

Aix-Marseille Université, France

*Correspondence:

Svenja Halfter

Svenja.Halfter@utas.edu.au

Specialty section:

This article was submitted to

Marine Biogeochemistry,

a section of the journal

Frontiers in Marine Science

Received: 31 May 2020 Accepted: 11 September 2020

Published: 30 September 2020

Citation:

Halfter S, Cavan EL,

Swadling KM, Eriksen RS and

Boyd PW (2020) The Role

of Zooplankton in Establishing Carbon

Export Regimes in the Southern

Ocean - A Comparison of Two

Representative Case Studies

in the Subantarctic Region.

Front. Mar. Sci. 7:567917.

doi: 10.3389/fmars.2020.567917

\author{
Svenja Halfter ${ }^{1 *}$, Emma L. Cavan ${ }^{2}$, Kerrie M. Swadling ${ }^{1}$, Ruth S. Eriksen ${ }^{1,3}$ and \\ Philip W. Boyd ${ }^{1}$
}

${ }^{1}$ Institute for Marine and Antarctic Studies, University of Tasmania, Hobart, TAS, Australia, ${ }^{2}$ Department of Life Sciences, Imperial College London, Berkshire, United Kingdom, ${ }^{3}$ CSIRO Oceans and Atmosphere, Hobart, TAS, Australia

Marine ecosystems regulate atmospheric carbon dioxide levels by transporting and storing photosynthetically fixed carbon in the ocean's interior. In particular, the subantarctic and polar frontal zone of the Southern Ocean is a significant region for physically driven carbon uptake due to mode water formation, although it is under-studied concerning biologically mediated uptake. Regional differences in iron concentrations lead to variable carbon export from the base of the euphotic zone. Contrary to our understanding of export globally, where high productivity results in high export, naturally iron-fertilized regions exhibit low carbon export relative to their surface productivity, while HNLC (High Nutrient, Low Chlorophyll) waters emerge as a significant area for carbon export. Zooplankton, an integral part of the oceanic food web, play an important role in establishing these main carbon export regimes. In this mini review, we explore this role further by focusing on the impact of grazing and the production of fecal pellets on the carbon flux. The data coverage in the subantarctic region will be assessed by comparing two case studies - the ironreplete Kerguelen Plateau and the HNLC region south of Australia. We then discuss challenges in evaluating the contributions of zooplankton to carbon flux, namely gaps in seasonal coverage of sampling campaigns, the use of non-standardized and biased methods and under-sampling of the mesopelagic zone, an important area of carbon remineralization. More integrated approaches are necessary to improve present estimates of zooplankton-mediated carbon export in the Southern Ocean.

Keywords: biological carbon pump, zooplankton, southern ocean, subpolar, carbon cycle

\section{INTRODUCTION}

The fixation of inorganic carbon through photosynthesis by phytoplankton, and subsequent export and sequestration to deeper waters, is termed the Biological Carbon Pump (BCP). Without this process, atmospheric $\mathrm{CO}_{2}$ levels would be $200 \mathrm{ppm}$ higher than they are today (Parekh et al., 2006; Henson et al., 2019), thus the BCP is a critical component of climate regulation. Zooplankton 
are part of the BCP, via ingestion of lower trophic levels, fecal pellet and carcass production and respiration of $\mathrm{CO}_{2}$ (SchnackSchiel and Isla, 2005; Turner, 2015; Steinberg and Landry, 2017). Furthermore, they actively transport carbon below the thermocline during daily migration and seasonal descent to overwinter at depth (Jónasdóttir et al., 2015; Klevjer et al., 2016; Steinberg and Landry, 2017; Record et al., 2018; Boyd et al., 2019). The role of zooplankton in the BCP is well-studied in some parts of the global ocean, e.g., the North Atlantic and the oxygen minimum zones in the Pacific (Jónasdóttir et al., 2015; Cavan et al., 2017), however, is less understood in the Southern Ocean.

The Southern Ocean plays a significant role in the functioning of the Earth system (Lumpkin and Speer, 2007; Mayewski et al., 2009), and provides important ecosystem services, such as climate regulation and nutrient recycling (Millennium Ecosystem Assessment, 2005). The region between the Subtropical Front and the Polar Front encompasses a large area of the Southern Ocean (hereafter called the "subantarctic region") and represents an important carbon sink, as the formation of intermediate and mode waters in this region contributes notably to the sequestration of atmospheric $\mathrm{CO}_{2}$ (Orsi et al., 1995; Sabine et al., 2004; Eriksen et al., 2018). Large parts of the subantarctic region are characterized by HNLC (High Nutrient, Low Chlorophyll) conditions: low iron concentrations in surface waters limit the uptake of macronutrients, such as phosphate and nitrate, and hence, restrict phytoplankton growth (Bucciarelli et al., 2001; Trull et al., 2001). In contrast, naturally iron-fertilized regions such as downstream of the Kerguelen Plateau, in the Indian sector of the Southern Ocean, are characterized by high primary production (Mosseri et al., 2008; Cavagna et al., 2015). However, high production does not always equal high carbon export as estimated from global models (e.g., Dunne et al., 2005; Laws et al., 2011) or sediment trap data (e.g., Marsay et al., 2015). Many reported an inverse relationship between primary production and export efficiency for the Southern Ocean (e.g., Maiti et al., 2013; Cavan et al., 2015; Laurenceau-Cornec et al., 2015; Le Moigne et al., 2016), which can be found at our study sites as well. While the Kerguelen Plateau is characterized as a HBLE (High Biomass, Low Export) region, the HNLC waters exhibit a relatively high carbon export below the mixed layer (Trull et al., 2001; Lam and Bishop, 2007; Ebersbach et al., 2011; Rembauville et al., 2015b). This mini review aims to understand the role that zooplankton play in establishing the characteristic carbon export regimes in the Southern Ocean by grazing on lower trophic levels and forming and repackaging sinking particles (Lam and Bishop, 2007). After a summary of the current state of knowledge, we also list contemporary knowledge gaps and propose future research priorities.

\section{TWO CONTRASTING EXPORT REGIONS}

The Kerguelen Plateau, located on the $70^{\circ} \mathrm{E}$ meridian, forms a naturally iron-fertilized region in the Polar Frontal Zone (PFZ) at the border of the Antarctic zone, with iron concentrations ranging from 0.45 to $0.7 \mathrm{nM}$ in spring, decreasing to $0.09 \mathrm{nM}$ in late summer due to phytoplankton growth (Table 1;
TABLE 1 | Comparison of environmental parameters and plankton groups between the HBLE Kerguelen Plateau and the HNLC waters south of Australia.

\begin{tabular}{|c|c|c|}
\hline Parameter & $\begin{array}{l}\text { Kerguelen Plateau } \\
\text { (HBLE) }\end{array}$ & HNLC waters \\
\hline Iron levels & $\begin{array}{l}0.45-0.7 \text { nM (spring), } \\
0.09 \text { nM (summer) (1)(2) }\end{array}$ & 0.05-0.11 nM (summer/autumn) ${ }^{(3)}$ \\
\hline $\begin{array}{l}\text { Phytoplankton } \\
\text { biomass }\end{array}$ & $\begin{array}{l}\text { High } \\
\left(>2.5 \mathrm{mg} \mathrm{Chl} \mathrm{a} \mathrm{m}^{-3}\right)^{(4)}\end{array}$ & Low (<0.6 mg Chl a m²) (5) \\
\hline $\begin{array}{l}\text { Dominant } \\
\text { phytoplankton }\end{array}$ & $\begin{array}{l}\text { Diatoms and } \\
\text { dinoflagellates (6)(7)(8)(9) }\end{array}$ & $\begin{array}{l}\text { Coccolithophorids and other } \\
\text { prymnesiophytes, cyanobacteria, } \\
\text { autotrophic flagellates and pennate } \\
\text { diatoms }(10)(11)(12)(13)(14)\end{array}$ \\
\hline $\begin{array}{l}\text { Dominant } \\
\text { zooplankton }\end{array}$ & $\begin{array}{l}\text { Large and medium-sized } \\
\text { calanoid copepods, } \\
\text { Oithonidae, pteropods }{ }^{(15)}\end{array}$ & $\begin{array}{l}\text { Oithona similis, foraminiferans, } \\
\text { appendicularians, calanoid } \\
\text { copepods, pteropods and salps }{ }^{(16)}\end{array}$ \\
\hline POC fluxes & $66 \mathrm{mg} \mathrm{C} \mathrm{m}^{-2} \mathrm{~d}^{-1}$ (17)(a) & $127.2 \mathrm{mg} \mathrm{C} \mathrm{m}^{-2} \mathrm{~d}^{-1}$ \\
\hline e-ratio & $0.03^{(17)(a)}$ & $0.16^{(18)(b)}$ \\
\hline
\end{tabular}

(1) Blain et al., 2001, (2) Blain et al., 2008, (3) Cassar et al., 2011, (4) Blain et al., 2007, (5) Trull et al., 2019, (6) Armand et al., 2008, (7) Christaki et al., 2008, (8) Christaki et al., 2015 (9) Lasbleiz et al., 2016, (10) Trull et al., 2001, (11) Kopczynska et al., 2001, (12) Odate and Fukuchi, 1995, (13) Eriksen et al., 2018, (14) de Salas et al., 2011 (15) Carlotti et al., 2015, (16) Hunt and Hosie, 2006, (17) LaurenceauCornec et al., 2015, (18) Ebersbach et al., 2011. (a) High phytoplankton biomass site (A3-2). (b) SOTS site. Examples of carbon flux and e-ratios in the two regions are also given. The POC fluxes are estimated from polyacrylamide gel traps at $200 \pm 10 \mathrm{~m}$ and $240 \mathrm{~m}$ depth on the Kerguelen Plateau and in the HNLC region, respectively. The e-ratio is an indicator for export efficiency and is calculated as the ratio between POC flux and primary productivity. Note that Laurenceau-Cornec et al. (2015) use net primary productivity (NPP) in the euphotic zone to calculate the e-ratio, while Ebersbach et al. (2011) use gross primary productivity (GPP).

Blain et al., 2001, 2008). This review focuses on the northern Kerguelen Plateau, which is separated from the southern part by the Fawn Trough at around $56^{\circ} \mathrm{S}$ (Park et al., 2014; Koubbi et al., 2016). The topography forces the Antarctic Polar Front to pass above the plateau south of the Kerguelen Islands, which introduces iron from the sediments (Blain et al., 2001), and leads to intensive seasonal phytoplankton blooms downstream of the plateau, with peaks of more than $2.5 \mathrm{mg} \mathrm{Chl} \mathrm{a} \mathrm{m}{ }^{-3}$ (Blain et al., 2007, 2013; Rembauville et al., 2015b; Schallenberg et al., 2018). Blooms over the shallow plateau last the whole summer, while the bloom period over deep waters is only observed in spring for $\sim 1$ month (Schallenberg et al., 2018). The dominating phytoplankton are diatoms and dinoflagellates (Armand et al., 2008; Christaki et al., 2008, 2015; Lasbleiz et al., 2016). The zooplankton community consists of large and medium-sized calanoid copepods and small copepods in the family Oithonidae (Figure 1; Carlotti et al., 2015). Non-copepod taxa account for 4$8 \%$ of the total zooplankton community, though pteropods can be abundant over the shelf (7-12\% of total abundance, Carlotti et al., 2008). Although the biomass in the pelagic ecosystem is high, the export flux is generally low $\left(<0.5 \mathrm{mmol}\right.$ POC $\mathrm{m}^{-2}$ $\mathrm{d}^{-1}, 289 \mathrm{~m}$ depth), except for short-lived (<14 days) export pulses in summer (up to $1.6 \mathrm{mmol} \mathrm{m} \mathrm{m}^{-2} \mathrm{~d}^{-1}$ ) (Rembauville et al., 2014). Hence, the Kerguelen Plateau is considered to be an HBLE environment (Lam and Bishop, 2007; Rembauville et al., 2014).

In comparison to the Kerguelen Plateau, the HNLC waters south of Australia exhibit lower iron concentrations and phytoplankton biomass, but relatively higher POC export flux 


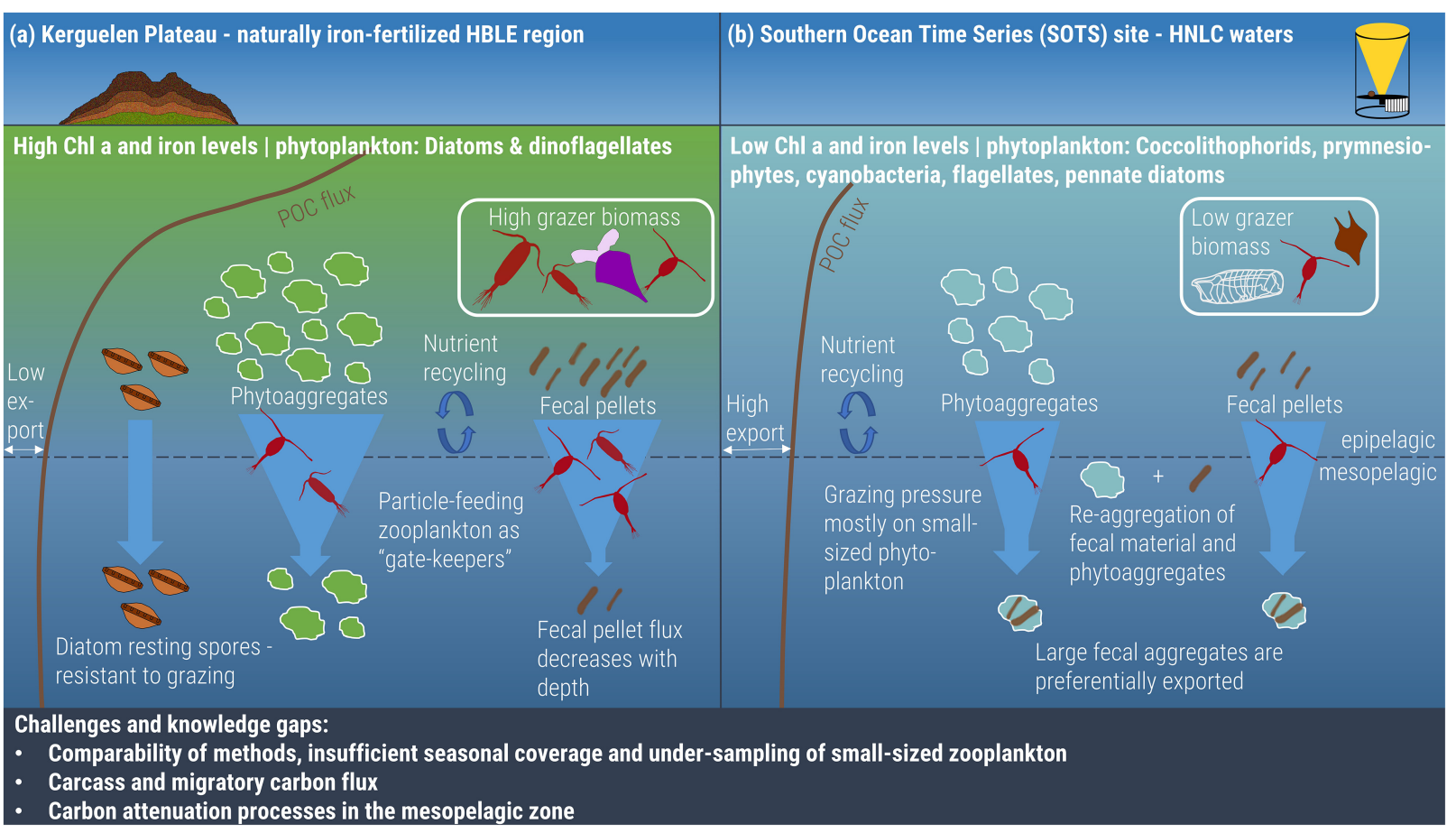

FIGURE 1 | The zooplankton-mediated carbon cycle in summer on the naturally iron-fertilized Kerguelen Plateau (a) compared to the HNLC waters around SOTS (b). On the Kerguelen Plateau, high iron levels lead to high chlorophyll a as a proxy for algae biomass at the surface. The diverse zooplankton community feeds on the sinking particle flux and acts as a "gate-keeper" to the deeper ocean by ingesting and fragmenting sinking particles and, consequently, significantly reducing the export flux out of the epipelagic. The main export particles are diatom resting spores, which bypass the intense grazing pressure, followed by fecal pellets. At SOTS, iron levels are lower and support a more diverse phytoplankton community, but with lower biomass, which, in turn, affects zooplankton community composition and biomass. The grazing pressure during summer is focused mostly on picoplankton, which leaves large particles for export. Grazing and fragmentation of particles at both sites increases nutrient recycling in the upper water column. Challenges and gaps in knowledge in aspects of the zooplankton-mediated carbon pump are highlighted.

(Table 1). We focus on the region around the Southern Ocean Time Series (SOTS) site at $142^{\circ} \mathrm{E}$ and $47^{\circ} \mathrm{S}$, which is representative of a broad HNLC region of the $\mathrm{SAZ}$ between $90^{\circ} \mathrm{E}$ and $140^{\circ} \mathrm{E}$ (Sedwick et al., 1999; Shadwick et al., 2015). Phytoplankton growth is limited by low iron $(0.05-0.11 \mathrm{nM}$ in summer/autumn and insufficient light conditions due to high cloud cover (Sedwick et al., 1999; Cassar et al., 2011). The phytoplankton community is dominated by nanoplankton and picoplankton, coccolithophorids and other prymnesiophytes (such as Phaeocystis antarctica), cyanobacteria and autotrophic flagellates (Odate and Fukuchi, 1995; Kopczynska et al., 2001; Trull et al., 2001; Eriksen et al., 2018). Diatoms are mostly lightly silicified pennate diatoms rather than centric forms (de Salas et al., 2011). Phytoplankton biomass is low throughout the year, with chlorophyll a values generally below $0.6 \mathrm{mg} \mathrm{m}^{-3}$ (Trull et al., 2019). This has implications for zooplankton, which is dominated by the copepod Oithona similis, foraminiferans, and appendicularians (Hunt and Hosie, 2006), rather than a community of calanoid copepods that are not able to accumulate enough resources to complete their life cycles. During summer, a small number of species of calanoid copepods, along with the pteropods Limacina spp. and regionally large blooms of the salp Salpa thompsoni, are also observed (Figure 1; Hunt and Hosie, 2006). Though primary production is low in surface waters, the total flux of POC is relatively high, e.g., $3.3 \pm 1.8 \mathrm{mmol}$ POC $\mathrm{m}^{-2} \mathrm{~d}^{-1}$ at $150 \mathrm{~m}$ water depth, measured with free-drifting PPS $3 / 3$ sediment traps (Ebersbach et al., 2011).

\section{CONTRIBUTIONS OF ZOOPLANKTON TO CARBON FLUX IN THE SUBANTARCTIC REGION}

\section{The Northern Kerguelen Plateau}

On the Kerguelen Plateau, zooplankton biomass increases four-fold from winter (July-August) to mid-summer (February) (Semelkina, 1993; Razouls et al., 1996; Carlotti et al., 2015). This is caused by (1) seasonal ontogenetic migrations by large calanoid copepods, such as Rhincalanus gigas and Calanoides acutus, which spend winter in diapause in deeper waters and ascend to surface in spring and (2) an increase in other species, e.g., Calanus simillimus and the smaller Oithona spp., that resume their population development from survivors of previous years to start reproduction in spring following the phytoplankton bloom (Atkinson, 1998; Schnack-Schiel, 2001; Carlotti et al., 2015). Remarkably, mesozooplankton (200 $\mu \mathrm{m}-20 \mathrm{~mm})$ consume only a small fraction of the phytoplankton biomass directly; e.g., 
Sarthou et al. (2008) measured a low ingestion of $1-10 \%$ of

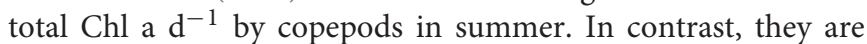
known to control protist growth by grazing (Carlotti et al., 2008). Heterotrophic protists, such as ciliates and some dinoflagellates in turn reduce the standing stock of pico- and nanophytoplankton and diatoms through grazing (Calbet and Landry, 2004; Calbet, 2008; Peloquin et al., 2011; Quéguiner, 2013). The grazing pressure by mesozooplankton on protozooplankton releases the top-down control on diatoms and favors phytoplankton blooms dominated by large diatoms (Henjes et al., 2007; Carlotti et al., 2015).

Additionally, zooplankton ingest and fragment particles, which enhances subsequent microbial respiration and increases the recycling of nutrients, e.g., iron (Sarthou et al., 2008) and ammonium (Mosseri et al., 2008). Grazing not only affects nutrient levels in surface waters but also the efficiency of carbon transfer (Dagg et al., 2014). The omnivorous and detritivorous zooplankton community acts as a "gatekeeper" in the mesopelagic zone (Figure 1): They ingest and fragment phytoplankton aggregates and fecal pellets that are quickly remineralized and retained in the surface layer (Iversen and Poulsen, 2007; Quéguiner, 2013; Dagg et al., 2014). Predominantly omnivorous and detritivorous copepod species in the genera Oithona and Oncaea/Triconia link the classical food web to the microbial loop (Atkinson, 1998; Pasternak et al., 2009). This efficient transfer of carbon to higher trophic levels or the microbial loop in surface waters leads to low export flux during most of the year and establishes the HBLE characteristics on the Kerguelen Plateau (Rembauville et al., 2014, 2015b). Despite the dominance of the carbon flux by fecal pellets in early spring ( $56 \pm 19 \%$ of total carbon flux, $200 \mathrm{~m}$, LaurenceauCornec et al., 2015), the fecal pellet flux decreases rapidly with depth, while diatom resting spores (resistant to grazing; Davis et al., 1980; Smetacek, 1985; Salter et al., 2012) and detrital aggregates dominate the deeper flux at $289 \mathrm{~m}$ (Cavan et al., 2019). This indicates preferential reprocessing and remineralization of fecal material over other particles in the mixed layer and upper mesopelagic, which leads to a lower fecal pellet flux similar to other iron-fertilized regions, e.g., South Georgia (Cavan et al., 2015; Rembauville et al., 2015a).

\section{HNLC Waters South of Australia}

The dominance of protozooplankton, small copepods and patchy salp blooms in HNLC waters, rather than a diverse and abundant mesozooplankton community as on the northern Kerguelen Plateau, results in control of the low phytoplankton biomass by protist grazing, and efficient remineralization of carbon and nutrients in the upper water column (Figure 1; Landry et al., 2002; Mayzaud et al., 2002; Pakhomov et al., 2002; Atkinson et al., 2004). Considering the omnivorous and detritivorous diet of Oithona similis (Takahashi et al., 2010), it would be expected that the POC export out of the epipelagic zone would be low, as ingestion and fragmentation of sinking particles increase the particle flux attenuation. However, studies such as SAZ-Sense in January/February 2007 have shown a relatively high POC transfer efficiency out of the mixed layer in the HNLC waters around SOTS, in comparison to other sites in the SAZ with higher iron levels or in the PFZ with a diatom-dominated phytoplankton community (Ebersbach et al., 2011). Even though the POC concentration was low at the surface $\left(5.2 \pm 0.9 \mathrm{mmol} \mathrm{m}^{-2}\right.$ $\left.\mathrm{d}^{-1}\right)$, the carbon export flux at SOTS was highest in both gel traps (8.1 mmol m $\mathrm{m}^{-2} \mathrm{~d}^{-1}$ at $290 \mathrm{~m}$ water depth) and PPS $3 / 3$ sediment traps $\left(3.3 \pm 1.8 \mathrm{mmol} \mathrm{m}^{-2} \mathrm{~d}^{-1}\right.$ at $150 \mathrm{~m}$ water depth) (Ebersbach et al., 2011).

The two main differences from the Kerguelen Plateau that cause the higher relative and total export flux in HNLC waters are a different zooplankton community composition and size fraction distribution (Figure 1). The dominant microzooplankton (20-200 $\mu \mathrm{m})$ and heterotrophic nanoflagellates at SOTS can consume $82 \%$ of the primary production per day in summer (Pearce et al., 2011). This is in line with Trull et al. (2019), who estimated a 10-fold higher grazing pressure in December compared to September as a function of zooplankton biomass. This grazing pressure focuses mostly on the picoplankton size fraction (0.2$2 \mu \mathrm{m})$, which leaves phytoplankton aggregates and other large particles for export below the mixed layer (Pearce et al., 2011). Omnivorous and detritivorous copepods are not as abundant as on the Kerguelen Plateau, which limits their abilities to efficiently reduce the sinking flux. Consequently, more particles (11-53\% of the primary production; Jacquet et al., 2011) are exported from HNLC surface waters (Figure 1), predominantly as fecal aggregates (pellets and fecal material reaggregated with phytodetritus; Ebersbach and Trull, 2008; Laurenceau-Cornec et al., 2015).

Our findings indicate that species composition and size fraction distribution are important factors in modifying the downward carbon flux and establishing a regime of low biomass at the surface but with relatively high carbon transfer efficiency. Hence, zooplankton play a more important role in the export regimes in the subantarctic region than previously thought. However, common algorithms to estimate the carbon export efficiency in the Southern Ocean, such as by Arteaga et al. (2018) or Britten et al. (2017), only include temperature, net primary production or silicate concentration and do not contain a zooplankton term. In contrast, our findings show that zooplankton, while being influenced by their physical environment and food availability, also control lower trophic levels and carbon export efficiency. Future research efforts should therefore focus on including zooplankton in the algorithms, for example as size fractions or a proportion of trophic mode (e.g., ratio between herbivore to detritivore zooplankton), and improve our estimation of carbon uptake by the Southern Ocean.

\section{CHALLENGES AND KNOWLEDGE GAPS}

\section{Comparability of Methods, Under-Sampling of Small-Sized Zooplankton and Insufficient Seasonal Coverage}

Different methodologies make it difficult to compare the zooplankton species composition and biomass between the 
subantarctic regions. Ship-based net deployments are temporally and spatially limited, but provide higher vertical resolution in the water column, while the Continuous Plankton Recorder (CPR) covers a large geographical area but only provides surface data and under-samples the vertical migrating community during the day (Carlotti et al., 2008, 2015; Dippner and Krause, 2013). Acoustic data provides information on distribution and biomass of certain size fractions over the whole annual cycle, but cannot provide species composition data (Trull et al., 2019). It is also important to note that both the CPR (silk mesh size $270 \mu \mathrm{m}$ ) and standard zooplankton nets with a mesh size of $>200 \mu \mathrm{m}$ are known to under-sample smaller-sized zooplankton, e.g., Oithonidae and copepodite stages (Gallienne and Robins, 2001) that dominate the community in HNLC waters. Finally, limited access to the subantarctic region due to logistical constraints results in a results in few winter datasets, as the sampling campaigns by research and supply vessels are mostly focused on the summer season.

\section{Understudied Carbon Pathways - Zooplankton Carcass and Migratory Flux}

As the literature on other high latitude systems suggests, zooplankton carcass flux can be a seasonally significant contribution to total carbon flux (Sampei et al., 2012; Daase et al., 2014; Tang and Elliott, 2014). However, data on drivers and rates of mortality and carcass flux from the Southern Ocean are currently not available. The lack of data could lead to an underestimation of carbon flux, especially in the HNLC waters, where fast-sinking salp blooms could significantly increase the downward carbon flux as "jelly falls", e.g., by $330 \%$ in the Tasman Sea further north (Henschke et al., 2013). Similarly, active transport of carbon by zooplankton, both by diel and seasonal vertical migrators, is not well understood. Translating the seasonal changes in the distribution of acoustic scattering layers into transported carbon is not possible without information on species composition (Trull et al., 2019).

\section{The "Black Box": The Mesopelagic Zone}

The transfer efficiency of organic matter through the mesopelagic $(\sim 200-1000 \mathrm{~m})$ is driven by plankton species composition in the epi- and mesopelagic (Lam et al., 2011). Studies such as Liszka et al. (2019); Manno et al. (2015) and Marsay et al. (2015) suggest that vertical distribution of zooplankton, community composition, and feeding behavior, along with temperature in the mesopelagic, are important in shaping the downward carbon flux. However, mesopelagic processes, such as respiration and remineralization of organic material and food web interactions, are not well understood (Robinson et al., 2010). Sampling campaigns in both regions rarely include the mesopelagic: while zooplankton studies on the Kerguelen Plateau focus on the upper $300 \mathrm{~m}$ of the water column, zooplankton data in the HNLC waters around SOTS were either collected from surface waters or from deeper, moored sediment traps. To increase our understanding of interactions between mesopelagic zooplankton, protists and bacteria, and their influence on particle formation and remineralization, future sampling campaigns need to focus on the mesopelagic.

\section{CONCLUSION AND OUTLOOK}

Zooplankton play an important role in the carbon flux of both subantarctic regions. On the Kerguelen Plateau, grazing by the mesozooplankton community limits protozooplankton growth, which releases the grazing pressure on phytoplankton. Zooplankton also fragment particles, leading to increased nutrient recycling, and contribute to the carbon flux by producing fecal pellets. High rates of omnivory and detritivory result in a low export flux and establish the HBLE conditions on the plateau. In contrast, the dominance of smaller-sized zooplankton and heterotrophic protists in HNLC waters leads to high grazing pressure on picoplankton, which leaves large aggregates and fecal pellets for export. The lower total abundance of detritus-feeders results in a larger export of fecal aggregates. Knowledge gaps, resulting from limited seasonal coverage, non-standardization and bias of methods between sampling campaigns, and under-sampling of the mesopelagic zone, impede our understanding of zooplankton-mediated carbon flux, especially of the carcass and migratory flux. To predict future changes in marine carbon storage efficiency, it is important to focus research efforts on the zooplankton-mediated carbon flux. The inclusion of, for example, zooplankton size fractions or trophic modes in algorithms can refine predictions of carbon export in the Southern Ocean. More integrated research approaches, e.g., using the network of biogeochemical Argo floats in combination with stationary moorings (e.g., Rembauville et al., 2017; Trull et al., 2019), are necessary to improve inter-seasonal and spatial data coverage of the Biological Carbon Pump in the Southern Ocean.

\section{AUTHOR CONTRIBUTIONS}

SH designed and wrote the review and produced the infographic, with edits from all co-authors.

\section{FUNDING}

SH and PB were funded by the Australian Research Council through a Laureate awarded to PB (FL160100131). EC was supported by a Natural Environment Research Council grant NE/S000348/1. The Southern Ocean Time Series Observatory is part of the Integrated Marine Observing System (IMOS). IMOS is enabled by the National Collaborative Research Infrastructure Strategy (NCRIS). It is operated by a consortium of institutions as an unincorporated joint venture, with the University of Tasmania as Lead Agent.

\section{ACKNOWLEDGMENTS}

We thank the three reviewers who provided valuable comments on the manuscript. 


\section{REFERENCES}

Armand, L. K., Cornet-Barthaux, V., Mosseri, J., and Quéguiner, B. (2008). Late summer diatom biomass and community structure on and around the naturally iron-fertilised Kerguelen Plateau in the Southern Ocean. Deep Sea Res. Part II Top. Stud. Oceanogr. 55, 653-676. doi: 10.1016/j.dsr2.2007.12.031

Arteaga, L., Haëntjens, N., Boss, E., Johnson, K. S., and Sarmiento, J. L. (2018). Assessment of export efficiency equations in the southern ocean applied to satellite-based net primary production. J. Geophys. Res. Oceans 123, 2945-2964. doi: 10.1002/2018JC013787

Atkinson, A. (1998). Life cycle strategies of epipelagic copepods in the Southern Ocean. J. Mar. Syst. 15, 289-311. doi: 10.1016/S0924-7963(97)00081-X

Atkinson, A., Siegel, V., Pakhomov, E., and Rothery, P. (2004). Long-term decline in krill stock and increase in salps within the Southern Ocean. Nature 432, 100-103. doi: 10.1038/nature02996

Blain, S., Quéguiner, B., Armand, L., Belviso, S., Bombled, B., Bopp, L., et al. (2007). Effect of natural iron fertilization on carbon sequestration in the Southern Ocean. Nature 446, 1070-1074. doi: 10.1038/nature05700

Blain, S., Renaut, S., Xing, X., Claustre, H., and Guinet, C. (2013). Instrumented elephant seals reveal the seasonality in chlorophyll and light-mixing regime in the iron-fertilized Southern Ocean. Geophys. Res. Lett. 40, 6368-6372. doi: 10.1002/2013GL058065

Blain, S., Sarthou, G., and Laan, P. (2008). Distribution of dissolved iron during the natural iron-fertilization experiment KEOPS (Kerguelen Plateau, Southern Ocean). Deep Sea Res. Part II Top. Stud. Oceanogr. 55, 594-605. doi: 10.1016/j. dsr2.2007.12.028

Blain, S., Tréguer, P., Belviso, S., Bucciarelli, E., Denis, M., Desabre, S., et al. (2001). A biogeochemical study of the island mass effect in the context of the iron hypothesis: Kerguelen Islands, Southern Ocean. Deep Sea Res. Part I Oceanogr. Res. Pap. 48, 163-187. doi: 10.1016/S0967-0637(00)00047-9

Boyd, P. W., Claustre, H., Levy, M., Siegel, D. A., and Weber, T. (2019). Multifaceted particle pumps drive carbon sequestration in the ocean. Nature 568 327-335. doi: 10.1038/s41586-019-1098-2

Britten, G. L., Wakamatsu, L., and Primeau, F. W. (2017). The temperature-ballast hypothesis explains carbon export efficiency observations in the Southern Ocean. Geophys. Res. Lett. 44, 1831-1838. doi: 10.1002/2016GL072378

Bucciarelli, E., Blain, S., and Tréguer, P. (2001). Iron and manganese in the wake of the Kerguelen Islands (Southern Ocean). Mar. Chem. 73, 21-36. doi: 10.1016/ S0304-4203(00)00070-0

Calbet, A. (2008). The trophic roles of microzooplankton in marine systems. ICES J. Mar. Sci. 65, 325-331. doi: 10.1093/icesjms/fsn013

Calbet, A., and Landry, M. R. (2004). Phytoplankton growth, microzooplankton grazing, and carbon cycling in marine systems. Limnol. Oceanogr. 49, 51-57. doi: 10.4319/lo.2004.49.1.0051

Carlotti, F., Jouandet, M. P., Nowaczyk, A., Harmelin-Vivien, M., Lefèvre, D., Richard, P., et al. (2015). Mesozooplankton structure and functioning during the onset of the Kerguelen phytoplankton bloom during the KEOPS2 survey. Biogeosciences 12, 4543-4563. doi: 10.5194/bg-12-4543-2015

Carlotti, F., Thibault-Botha, D., Nowaczyk, A., and Lefe, D. (2008). Zooplankton community structure, biomass and role in carbon fluxes during the second half of a phytoplankton bloom in the eastern sector of the Kerguelen Shelf (January February 2005). Deep Sea Res. Part II 55, 720-733. doi: 10.1016/j.dsr2.2007. 12.010

Cassar, N., DiFiore, P. J., Barnett, B. A., Bender, M. L., Bowie, A. R., Tilbrook, B., et al. (2011). The influence of iron and light on net community production in the Subantarctic and Polar Frontal Zones. Biogeosciences 8, 227-237. doi: 10.5194/bg-8-227-2011

Cavagna, A. J., Fripiat, F., Elskens, M., Mangion, P., Chirurgien, L., Closset, I., et al. (2015). Production regime and associated N cycling in the vicinity of Kerguelen Island, Southern Ocean. Biogeosciences 12, 6515-6528. doi: 10.5194/ bg-12-6515-2015

Cavan, E. L., Laurenceau-Cornec, E. C., Bressac, M., and Boyd, P. W. (2019). Exploring the ecology of the mesopelagic biological pump. Prog. Oceanogr. 176:102125. doi: 10.1016/j.pocean.2019.102125

Cavan, E. L., Le Moigne, F. A. C., Poulton, A. J., Tarling, G. A., Ward, P., Daniels, C. J., et al. (2015). Zooplankton fecal pellets control the attenuation of particulate organic carbon flux in the Scotia Sea, Southern Ocean. Geophys. Res. Lett. 42, 821-830. doi: 10.1002/2014gl062744
Cavan, E. L., Trimmer, M., Shelley, F., and Sanders, R. (2017). Remineralization of particulate organic carbon in an ocean oxygen minimum zone. Nat. Commun. 8:14847. doi: $10.1038 /$ ncomms 14847

Christaki, U., Georges, C., Genitsaris, S., and Monchy, S. (2015). Microzooplankton community associated with phytoplankton blooms in the naturally ironfertilized Kerguelen area (Southern Ocean). FEMS Microbiol. Ecol. 91:fiv068. doi: 10.1093/femsec/fiv068

Christaki, U., Obernosterer, I., Van Wambeke, F., Veldhuis, M., Garcia, N., and Catala, P. (2008). Microbial food web structure in a naturally iron-fertilized area in the Southern Ocean (Kerguelen Plateau). Deep Sea Res. Part II Top. Stud. Oceanogr. 55, 706-719. doi: 10.1016/j.dsr2.2007.12.009

Daase, M., Varpe, O., and Falk-Petersen, S. (2014). Non-consumptive mortality in copepods: occurrence of Calanus spp. Carcasses in the Arctic Ocean during winter. J. Plankton Res. 36, 129-144. doi: 10.1093/plankt/fbt079

Dagg, M. J., Jackson, G. A., and Checkley, D. M. (2014). The distribution and vertical flux of fecal pellets from large zooplankton in Monterey bay and coastal California. Deep Sea Res. Part I Oceanogr. Res. Pap. 94, 72-86. doi: 10.1016/j. dsr.2014.09.001

Davis, C. O., Hollibaugh, J. T., Seibert, D. L. R., Thomas, W. H., and Harrison, P. J. (1980). Formation of resting spores by Leptocylindrus danicus (Bacillariophyceae) in a controlled experimental ecosystem. J. Phycol. 16, 296302. doi: 10.1111/j.1529-8817.1980.tb03034.x

de Salas, M. F., Eriksen, R., Davidson, A. T., and Wright, S. W. (2011). Protistan communities in the Australian sector of the Sub-Antarctic Zone during SAZSense. Deep Sea Res. Part II Top. Stud. Oceanogr. 58, 2135-2149. doi: 10.1016/j. dsr2.2011.05.032

Dippner, J. W., and Krause, M. (2013). Continuous plankton recorder underestimates zooplankton abundance. J. Mar. Syst. 111-112, 263-268. doi: 10.1016/j.jmarsys.2012.09.009

Dunne, J. P., Armstrong, R. A., Gnanadesikan, A., and Sarmiento, J. L. (2005). Empirical and mechanistic models for the particle export ratio. Glob. Biogeochem. Cycles 19:GB4026. doi: 10.1029/2004GB002390

Ebersbach, F., and Trull, T. W. (2008). Sinking particle properties from polyacrylamide gels during the KErguelen Ocean and Plateau compared Study (KEOPS): zooplankton control of carbon export in an area of persistent natural iron inputs in the Southern Ocean. Limnol. Oceanogr. 53, 212-224. doi: 10.4319/ lo.2008.53.1.0212

Ebersbach, F., Trull, T. W., Davies, D. M., and Bray, S. G. (2011). Deep-sea research II controls on mesopelagic particle fluxes in the sub-antarctic and polar frontal zones in the Southern Ocean south of Australia in summer - Perspectives from free-drifting sediment traps. Deep Sea Res. Part II 58, 2260-2276. doi: 10.1016/j.dsr2.2011.05.025

Eriksen, R., Trull, T. W., Davies, D., Jansen, P., Davidson, A. T., Westwood, K., et al. (2018). Seasonal succession of phytoplankton community structure from autonomous sampling at the Australian Southern Ocean Time Series (SOTS) observatory. Mar. Ecol. Prog. Ser. 589, 13-31. doi: 10.3354/meps1 2420

Gallienne, C. P., and Robins, D. B. (2001). Is Oithona the most important copepod in the world's oceans? J. Plankton Res. 23, 1421-1432. doi: 10.1093/plankt/23. 12.1421

Henjes, J., Assmy, P., Klaas, C., Verity, P., and Smetacek, V. (2007). Response of microzooplankton (protists and small copepods) to an iron-induced phytoplankton bloom in the Southern Ocean (EisenEx). Deep Sea Res. Part I Oceanogr. Res. Pap. 54, 363-384. doi: 10.1016/j.dsr.2006.12.004

Henschke, N., Bowden, D. A., Everett, J. D., Holmes, S. P., Kloser, R. J., Lee, R. W., et al. (2013). Salp-falls in the Tasman Sea: a major food input to deep-sea benthos. Mar. Ecol. Prog. Ser. 491, 165-175. doi: 10.3354/meps 10450

Henson, S., Le Moigne, F., and Giering, S. (2019). Drivers of Carbon Export Efficiency in the Global Ocean. Glob. Biogeochem. Cycles 33, 891-903. doi: $10.1029 / 2018 \mathrm{gb} 006158$

Hunt, B., and Hosie, G. (2006). The seasonal succession of zooplankton in the Southern Ocean south of Australia, part II: the Sub-Antarctic to Polar Frontal Zones. Deep Sea Res. Part I Oceanogr. Res. Pap. 53, 1203-1223. doi: 10.1016/j. dsr.2006.05.002

Iversen, M. H., and Poulsen, L. K. (2007). Coprorhexy, coprophagy, and coprochaly in the copepods Calanus helgolandicus, Pseudocalanus elongatus, and Oithona similis. Mar. Ecol. Prog. Ser. 350, 79-89. doi: 10.3354/meps07095 
Jacquet, S. H. M., Lam, P. J., Trull, T., and Dehairs, F. (2011). Carbon export production in the subantarctic zone and polar front zone south of Tasmania. Deep Sea Res. Part II Top. Stud. Oceanogr. 58, 2277-2292. doi: 10.1016/j.dsr2. 2011.05.035

Jónasdóttir, S. H., Visser, A. W., Richardson, K., and Heath, M. R. (2015). Seasonal copepod lipid pump promotes carbon sequestration in the deep North Atlantic. Proc. Natl. Acad. Sci. U.S.A. 112, 12122-12126. doi: 10.1073/pnas.1512 110112

Klevjer, T. A., Irigoien, X., Rostad, A., Fraile-Nuez, E., Benitez-Barrios, V. M., and Kaartvedt, S. (2016). Large scale patterns in vertical distribution and behaviour of mesopelagic scattering layers. Sci. Rep. 6:19873. doi: 10.1038/srep 19873

Kopczynska, E. E., Dehairs, F., Elskens, M., and Wright, S. (2001). Phytoplankton and microzooplankton variability between the Subtropical and Polar Fronts south of Australia: thriving under regenerative and new production in late summer. J. Geophys. Res. Oceans 106, 31597-31609. doi: 10.1029/ 2000JC000278

Koubbi, P., Guinet, C., Alloncle, N., Ameziane, N., Azam, C. S., Baudena, A., et al. (2016). Ecoregionalisation of the Kerguelen and Crozet Islands Oceanic Zone Part I: Introduction and Kerguelen Oceanic Zone (Issue Umr 7159). Available online at: https://thomassaucede.files.wordpress.com/2016/10/ koubbi-et-al-emm-kerguelen-201606171836.pdf (accessed July, 2020).

Lam, P. J., and Bishop, J. K. B. (2007). High biomass, low export regimes in the Southern Ocean. Deep Sea Res. Part II Top. Stud. Oceanogr. 54, 601-638. doi: 10.1016/j.dsr2.2007.01.013

Lam, P. J., Doney, S. C., and Bishop, J. K. B. (2011). The dynamic ocean biological pump: insights from a global compilation of particulate organic carbon, $\mathrm{CaCO}$, and opal concentration profiles from the mesopelagic. Glob. Biogeochem. Cycles 25:GB3009. doi: 10.1029/2010GB003868

Landry, M. R., Selph, K. E., Brown, S. L., Abbott, M. R., Measures, C. I., Vink, S., et al. (2002). Seasonal dynamics of phytoplankton in the Antarctic Polar Front region at $170^{\circ}$ W. Deep Sea Res. Part II Top. Stud. Oceanogr. 49, 1843-1865. doi: 10.1016/S0967-0645(02)00015-2

Lasbleiz, M., Leblanc, K., Armand, L. K., Christaki, U., Georges, C., Obernosterer, I., et al. (2016). Composition of diatom communities and their contribution to plankton biomass in the naturally iron-fertilized region of Kerguelen in the Southern Ocean. FEMS Microbiol. Ecol. 92:fiw171. doi: 10.1093/femsec/fiw171

Laurenceau-Cornec, E. C., Trull, T. W., Davies, D. M., Bray, S. G., Doran, J., Planchon, F., et al. (2015). The relative importance of phytoplankton aggregates and zooplankton fecal pellets to carbon export: insights from freedrifting sediment trap deployments in naturally iron-fertilised waters near the Kerguelen Plateau To cite this version: HAL Id: hal-0. Biogeosciences 12, 1007-1027. doi: 10.5194/bg-12-1007-2015

Laws, E. A., D'Sa, E., and Naik, P. (2011). Simple equations to estimate ratios of new or export production to total production from satellite-derived estimates of sea surface temperature and primary production. Limnol. Oceanogr. Methods 9, 593-601. doi: 10.4319/lom.2011.9.593

Le Moigne, F. A. C., Henson, S., Cavan, E. L., Georges, C., Pabortsava, K., Achterberg, E. P., et al. (2016). What causes the inverse relationship between primary production and export efficiency in the Southern Ocean? Geophys. Res. Lett. 43, 4457-4466. doi: 10.1002/2016GL068480

Liszka, C. M., Manno, C., Stowasser, G., Robinson, C., and Tarling, G. A. (2019). Mesozooplankton community composition controls fecal pellet flux and remineralization depth in the Southern Ocean. Front. Mar. Sci. 6:230. doi: $10.3389 /$ fmars.2019.00230

Lumpkin, R., and Speer, K. (2007). Global ocean meridional overturning. J. Phys. Oceanogr. 37, 2550-2562. doi: 10.1175/JPO3130.1

Maiti, K., Charette, M. A., Buesseler, K. O., and Kahru, M. (2013). An inverse relationship between production and export efficiency in the Southern Ocean. Geophys. Res. Lett. 40, 1557-1561. doi: 10.1002/grl.50219

Manno, C., Stowasser, G., Enderlein, P., Fielding, S., and Tarling, G. A. (2015). The contribution of zooplankton faecal pellets to deep carbon transport in the Scotia Sea (Southern Ocean). Biogeosciences 12, 1955-1965. doi: 10.5194/bg-12-19552015

Marsay, C. M., Sanders, R. J., Henson, S. A., Pabortsava, K., Achterberg, E. P., and Lampitt, R. S. (2015). Attenuation of sinking particulate organic carbon flux through the mesopelagic ocean. Proc. Natl. Acad. Sci. U.S.A. 112, 1089-1094. doi: $10.1073 /$ pnas. 1415311112
Mayewski, P. A., Meredith, M. P., Summerhayes, C. P., Turner, J., Worby, A., Barrett, P. J., et al. (2009). State of the Antarctic and Southern Ocean climate system. Rev. Geophys. 47:RG1003. doi: 10.1029/2007RG000231

Mayzaud, P., Tirelli, V., Errhif, A., Labat, J. P., Razouls, S., and Perissinotto, R. (2002). Carbon intake by zooplankton. Importance and role of zooplankton grazing in the Indian sector of the Southern Ocean. Deep Sea Res. Part II Top. Stud. Oceanogr. 49, 3169-3187. doi: 10.1016/S0967-0645(02)00077-2

Millennium Ecosystem Assessment (2005). Ecosystems and Human Wellbeing: Current State and Trends Working Group of the Millennium Ecosystem Assessment. Washington, DC: Island Press, 948.

Mosseri, J., Queguiner, B., Armand, L., and Cornet-Barthaux, V. (2008). Impact of iron on silicon utilization by diatoms in the Southern Ocean: a case study of $\mathrm{Si} / \mathrm{N}$ cycle decoupling in a naturally iron-enriched area. Deep Sea Res. Part II Top. Stud. Oceanogr. 55, 801-819. doi: 10.1016/j.dsr2.2007.12.003

Odate, T., and Fukuchi, M. (1995). Distribution and community structure of picophytoplankton in the Southern Ocean during late austral summer of 1992. Proc. NIPR Symp. Polar Biol. Nat. Inst. Polar Res. 8, 86-100.

Orsi, A. H., Whitworth, T., and Nowlin, W. D. (1995). On the meridional extent and fronts of the Antarctic circumpolar current. Deep Sea. Res. 1 Oceanogr. Res. Pap. 42, 641-673. doi: 10.1016/0967-0637(95)00021-W

Pakhomov, E. A., Froneman, P. W., and Perissinotto, R. (2002). Salp/krill interactions in the Southern Ocean: spatial segregation and implications for the carbon flux. Deep Sea Res. Part II Top. Stud. Oceanogr. 49, 1881-1907. doi: 10.1016/S0967-0645(02)00017-6

Parekh, P., Dutkiewicz, S., Follows, M. J., and Ito, T. (2006). Atmospheric carbon dioxide in a less dusty world. Geophys. Res. Lett. 33:L03610. doi: 10.1029/ 2005GL025098

Park, Y.-H., Durand, I., Kestenare, E., Rougier, G., Zhou, M., d'Ovidio, F., et al. (2014). Polar Front around the Kerguelen Islands: an up-to-date determination and associated circulation of surface/subsurface waters. J. Geophys. Res. Oceans 119, 6575-6592. doi: 10.1002/2014JC010061

Pasternak, A., Hagen, W., Kattner, G., Michels, J., Graeve, M., and SchnackSchiel, S. B. (2009). Lipid dynamics and feeding of dominant Antarctic calanoid copepods in the eastern Weddell Sea in December. Polar Biol. 32, 1597-1606. doi: 10.1007/s00300-009-0658-6

Pearce, I., Davidson, A. T., Thomson, P. G., Wright, S., and van den Enden, R. (2011). Marine microbial ecology in the sub-Antarctic Zone: rates of bacterial and phytoplankton growth and grazing by heterotrophic protists. Deep Sea Res. Part II Top. Stud. Oceanogr. 58, 2248-2259. doi: 10.1016/j.dsr2.2011.05.030

Peloquin, J., Hall, J., Safi, K., Ellwood, M., Law, C. S., Thompson, K., et al. (2011). Control of the phytoplankton response during the SAGE experiment: a synthesis. Deep Sea Res. Part II Top. Stud. Oceanogr. 58, 824-838. doi: 10.1016/ j.dsr2.2010.10.019

Quéguiner, B. (2013). Iron fertilization and the structure of planktonic communities in high nutrient regions of the Southern Ocean. Deep Sea Res. Part II Top. Stud. Oceanogr. 90, 43-54. doi: 10.1016/j.dsr2.2012.07.024

Razouls, S., Koubbi, P., and Mayzaud, P. (1996). Spatio-temporal distribution of mesozooplankton in a sub-Antarctic coastal basin of the Kerguelen Archipelago (Southern Indian Ocean). Polar Biol. 16, 581-587. doi: 10.1007/BF02329055

Record, N. R., Ji, R., Maps, F., Varpe, Ø., Runge, J. A., Petrik, C. M., et al. (2018). Copepod diapause and the biogeography of the marine lipidscape. J. Biogeogr. 45, 2238-2251. doi: 10.1111/jbi.13414

Rembauville, M., Blain, S., Armand, L., Queguiner, B., and Salter, I. (2014). Export fluxes in a naturally fertilized area of the Southern Ocean, the Kerguelen Plateau: ecological vectors of carbon and biogenic silica to depth (Part 2). Biogeosci. Discuss. 11, 17089-17150. doi: 10.5194/bgd-11-17089-2014

Rembauville, M., Blain, S., Armand, L., Quéguiner, B., and Salter, I. (2015a). Export fluxes in a naturally iron-fertilized area of the Southern Ocean - Part 2: importance of diatom resting spores and faecal pellets for export. Biogeosciences 12, 3171-3195. doi: 10.5194/bg-12-3171-2015

Rembauville, M., Briggs, N., Ardyna, M., Uitz, J., Catala, P., Penkerc'h, C., et al. (2017). Plankton assemblage estimated with BGC-Argo floats in the Southern Ocean: implications for seasonal successions and particle export. J. Geophys. Res. Oceans 122, 8278-8292. doi: 10.1002/2017jc013067

Rembauville, M., Salter, I., Leblond, N., Gueneugues, A., and Blain, S. (2015b). Export fluxes in a naturally iron-fertilized area of the Southern Ocean - Part 1: seasonal dynamics of particulate organic carbon export from a moored sediment trap. Biogeosciences 12, 3153-3170. doi: 10.5194/bg-12-3153-2015 
Robinson, C., Steinberg, D. K., Anderson, T. R., Arístegui, J., Carlson, C. A., Frost, J. R., et al. (2010). Mesopelagic zone ecology and biogeochemistry - a synthesis. Deep Sea Res. Part II Top. Stud. Oceanogr. 57, 1504-1518. doi: 10.1016/j.dsr2. 2010.02.018

Sabine, C., Feely, R., Gruber, N., Key, R. M., Lee, K., Bullister, J. L., et al.. (2004). The oceanic sink for anthropogenic $\mathrm{CO}_{2}$. Science 305, 367-371. doi: 10.1126/ science. 1097403

Salter, I., Kemp, A. E. S., Moore, C. M., Lampitt, R. S., Wolff, G. A., and Holtvoeth, J. (2012). Diatom resting spore ecology drives enhanced carbon export from a naturally iron-fertilized bloom in the Southern Ocean. Glob. Biogeochem. Cycles 26:GB1014. doi: 10.1029/2010GB003977

Sampei, M., Sasaki, H., Forest, A., and Fortier, L. (2012). A substantial export flux of particulate organic carbon linked to sinking dead copepods during winter 2007-2008 in the Amundsen Gulf (southeastern Beaufort Sea, Arctic Ocean). Limnol. Oceanogr. 57, 90-96. doi: 10.4319/lo.2012.57.1.0090

Sarthou, G., Vincent, D., Christaki, U., Obernosterer, I., Timmermans, K. R., and Brussaard, C. P. D. (2008). The fate of biogenic iron during a phytoplankton bloom induced by natural fertilisation: impact of copepod grazing. Deep Sea Res. Part II Top. Stud. Oceanogr. 55, 734-751. doi: 10.1016/j.dsr2.2007. 12.033

Schallenberg, C., Bestley, S., Klocker, A., Trull, T. W., Davies, D. M., GaultRingold, M., et al. (2018). Sustained upwelling of subsurface iron supplies seasonally persistent phytoplankton blooms around the southern Kerguelen Plateau, Southern Ocean. J. Geophys. Res. Oceans 123, 5986-6003. doi: 10.1029/ 2018JC013932

Schnack-Schiel, S. B. (2001). "Aspects of the study of the life cycles of Antarctic copepods," in Copepoda: Developments in Ecology, Biology and Systematics, eds R. M. Lopes, J. W. Reid, and C. E. F. Rocha (Dordrecht: Springer), 9-24. doi: 10.1007/0-306-47537-5_2

Schnack-Schiel, S. B., and Isla, E. (2005). The role of zooplankton in the pelagicbenthic coupling of the Southern Ocean. Scientia Marina 69, 39-55. doi: 10.3989/scimar.2005.69s239

Sedwick, P. N., DiTullio, G. R., Hutchins, D. A., Boyd, W., Brian, F., Crossley, A. C., et al. (1999). Limitation of algal growth by iron deficiency in the Australian Subantarctic region. Geophys. Res. Lett. 26, 2865-2868. doi: 10.1029/ 1998GL002284

Semelkina, A. N. (1993). "Development of the zooplankton in the Kerguelen Island region in the years 1987-88," in Campagnes SKALP 1987 et 1988 aux Iles Kerguelen a Bord des Navires 'SKIF' et 'KALPER', ed. G. Duhamel (Paris: French Institute for Research), 90-104.
Shadwick, E. H., Trull, T. W., Tilbrook, B., Sutton, A. J., Schulz, E., and Sabine, C. L. (2015). Seasonality of biological and physical controls on surface ocean CO2 from hourly observations at the Southern Ocean Time Series site south of Australia. Glob. Biogeochem. Cycles 29, 223-238. doi: 10.1002/2014gb00 4906

Smetacek, V. S. (1985). Role of sinking in diatom life-history cycles: ecological, evolutionary and geological significance. Mar. Biol. 84, 239-251. doi: 10.1007/ BF00392493

Steinberg, D. K., and Landry, M. R. (2017). Zooplankton and the ocean carbon cycle. Annu. Rev. Mar. Sci. 9, 413-444. doi: 10.1146/annurev-marine-010814015924

Takahashi, K. T., Hosie, G. W., Kitchener, J. A., McLeod, D. J., Odate, T., and Fukuchi, M. (2010). Comparison of zooplankton distribution patterns between four seasons in the Indian Ocean sector of the Southern Ocean. Polar Sci. 4, 317-331. doi: 10.1016/j.polar.2010.05.002

Tang, K. W., and Elliott, D. T. (2014). Copepod carcasses: occurrence, fate and ecological importance. Copepods 255-278.

Trull, T. W., Bray, S. G., Manganini, S. J., Honjo, S., and Francois, R. (2001). Moored sediment trap measurements of carbon export in the Subantarctic and Polar Frontal Zones of the Southern Ocean, south of Australia. J. Geophys. Res. Oceans 106, 31489-31509. doi: 10.1029/2000JC000308

Trull, T. W., Jansen, P., Schulz, E., Weeding, B., Davies, D. M., Bray, S. G., et al. (2019). Autonomous multi-trophic observations of productivity and export at the Australian Southern Ocean Time Series (SOTS) reveal sequential mechanisms of physical-biological coupling. Front. Mar. Sci. 6:525. doi: 10. 3389/fmars.2019.00525

Turner, J. T. (2015). Zooplankton fecal pellets, marine snow, phytodetritus and the ocean's biological pump. Prog. Oceanogr. 130, 205-248. doi: 10.1016/j.pocean. 2014.08.005

Conflict of Interest: The authors declare that the research was conducted in the absence of any commercial or financial relationships that could be construed as a potential conflict of interest.

Copyright (C) 2020 Halfter, Cavan, Swadling, Eriksen and Boyd. This is an open-access article distributed under the terms of the Creative Commons Attribution License (CC BY). The use, distribution or reproduction in other forums is permitted, provided the original author(s) and the copyright owner(s) are credited and that the original publication in this journal is cited, in accordance with accepted academic practice. No use, distribution or reproduction is permitted which does not comply with these terms. 